\title{
IMPACT OF REPEATED YEARLY APPLICATIONS OF PROHEXADIONE-CALCIUM ON VEGETATIVE AND REPRODUCTIVE GROWTH OF 'GOLDEN DELICIOUS'/M.9 APPLE TREES
}

\author{
A. Nilgün ATAY ${ }^{1 *}$, Fatma KOYUNCU ${ }^{2}$ \\ ${ }^{1}$ Fruit Research Institute, 32500, Eğirdir, Isparta, TURKEY \\ ${ }^{2}$ Süleyman Demirel University, Faculty of Agriculture, Department of Horticulture, \\ 32000, Isparta, TURKEY
}

Received: October 2016; Accepted: April 2017

\begin{abstract}
Growth retardants have great potential to balance between vegetative and reproductive growth. To assess the effects of prohexadione-calcium (Pro-Ca, Regalis) on reproductive and vegetative growth, return bloom, fruit set, and also fruit quality in 'Golden Delicious' apple grafted on M.9 rootstock, an experiment was performed during 2010-2012. The applications of $125 \mathrm{mg} \mathrm{dm}^{-3}$ Pro-Ca on the same trees in each year resulted in a 40-43\% shoot length reducing. Internodes length decreased with Pro-Ca at about 30\%, while total node number was unaffected. Results indicate that Pro-Ca applications have no effects on tree trunk growth, flowering, yield, fruit set and development. Pro-Ca also didn't have any negative impact on fruit quality during the three consecutive years. Moreover, Pro-Ca resulted in higher fruit size compared to control in the third year of trial. The results of this experiment clearly suggest that fruit growers can use Pro$\mathrm{Ca}$ for the control of vegetative growth without having any negative effects on fruit quality and yield parameters. Once a full canopy has been achieved, annual shoot growth can be suppressed in the range of 20 to $30 \mathrm{~cm}$ with $125 \mathrm{mg} \mathrm{dm}^{-3}$ Pro-Ca treatment in 'Golden Delicious' apple trees.
\end{abstract}

Key words: alternate bearing, fruit quality, growth retardant, internode length, return bloom, shoot growth

\section{INTRODUCTION}

The importance of vegetative growth regulation in fruit growing is a well-known issue. An uncontrolled increase in vegetative growth negatively affects productivity, fruit quality, pests and diseases control as well as significantly increases the costs of pruning the trees (Forshey et al. 1992). The control of vegetative development is also very important in terms of adequate flower bud formation. There is an antagonistic relationship between shoot length and flowering (Forshey \& Elfving 1989; Tromp 2005).

Prohexadione, an active component of prohexadione-calcium (Pro-Ca), a gibberellin (GA) biosynthesis inhibitor, blocks the enzymes involved in the biosynthesis of GAs in the pathway between $\mathrm{GA}_{20}$ to $\mathrm{GA}_{1}$ (Rademacher \& Kober 2003). It has been suggested that using Pro-Ca is a good practice for the control of vegetative growth, especially in apple and pear trees (Costa et al. 2002; Elfving et al. 2003; Asin et al. 2007). Pro-Ca has some effects on shoot growth reduction of cherry (Elfving et al. 2005; Jacyna et al. 2012), walnut (Solar et al. 2008), citrus and avocado (Garner et al. 2010).

Pro-Ca has a significant impact on the suppression of fire blight disease caused by Erwinia amylovora in addition to the control of vegetative growth (Cline 2006). There are a few reports on Pro-Ca effect on flowering or alternate bearing (Byers et al. 2004; Cline et al. 2008). Nevertheless, there have been observations that prove that agents blocking GA biosynthesis and activity promote flower bud formation (Faust 1989; Costa et al. 2000). Improvement of red color intensity, increase of fruit $\mathrm{Ca}$ content, and reduction of diseases are other useful 
effects of Pro-Ca in addition to restriction of tree growth (Greene \& Autio 2002; Mata et al. 2006).

Pro-Ca applications are recommended just before or after the petal fall period (Rademacher \& Kober 2003). Also, shoot growth is very fast after full bloom, and more than $50 \%$ of total growth takes place in the spring. For this reason, early applications of Pro-Ca are very influential (Unrath 1999). On the other hand, cell division is most intense in this period which it is directly related to fruit size at harvest time (Westwood 1995). Therefore, lowdoses of Pro-Ca should not decrease the cell division rate (Greene 1999; Wertheim \& Webster 2005). The most appropriate Pro-Ca dose for apples is usually around $125-250 \mathrm{mg} \mathrm{dm}^{-3}$, and minimum 2 applications per season are needed (Evans et al. 1999; Cline 2006). However, half-life of Pro-Ca in plants is a few weeks. Pro-Ca does not have adverse effects on human health and environment due to the limited half-life (Evans et al. 1999; Wertheim \& Webster 2005).

The major apple growing area in Turkey is located in Isparta, and 'Golden Delicious' still represents almost half of total production (TSI 2013). Pro-Ca has been newly registered in Turkey for use on apples. The aim of this study was to investigate the long-term effects of continual application of Pro-Ca on the same trees. For this purpose, vegetative and reproductive growth, return bloom, fruit set, and also fruit quality were examined in the 'Golden Delicious' apples grafted on M.9 over three consecutive years.

\section{MATERIALS AND METHODS}

The experiment was carried out in the Fruit Research Station located in Turkey $\left(37^{\circ} 48^{\prime} 52.16^{\prime \prime} \mathrm{N}\right.$, $30^{\circ} 52^{\prime} 39.66^{\prime \prime}$ E, $920 \mathrm{~m}$ a.s.1). The 'Golden Delicious' apple trees on M.9 rootstock, planted with 3.5 $\times 1 \mathrm{~m}$, were five-years old at the time when the experiment started. The orchard was drip irrigated and fertilized according to soil analysis. The trees were not pruned during the course of the study to determine the actual return bloom. Experimental design was factorial randomized complete block, with 5 replicates using single tree per replication. The applications were performed on the trees of uniform structure in years 2010-2012. Pro-Ca (Regalis, BASF-The Chemical Company) was sprayed twice with 75 and $50 \mathrm{mg} \mathrm{dm}^{-3}$ at 3 week interval. The first spray was performed at petal fall stage using a lowpressure hand-wand sprayer and 11 of the relevant solution per tree. Before application, the $\mathrm{pH}$ of water was set at $4.5-5$ with $2 \mathrm{~N} \mathrm{HCl} \%$ and then Pro-Ca was added. The trees were well coated with the prepared solution with $0.1 \%$ Tween $20^{\circledR}$ (Merck, Schuchardt, Germany) to increase the efficiency of the chemicals. Control included the unsprayed trees.

Shoot development was determined on the same three bourse shoots per tree at two week intervals during vegetation period in 2010. Additionally, mean shoot length was measured on randomly selected ten bourse shoots taken from different parts of tree canopy following the terminal bud formation (the $3^{\text {rd }}$ week of July). Internodes length and node number were also recorded on these shoots. To construct fruit growth curves, fruit diameters were measured on three marked fruits at 2 week intervals from petal fall until harvest.

Flower density was recorded as the number of flower clusters per trunk cross-sectional area (TCSA) at pink bloom stage. Calculations of flowering index and cluster numbers per branch crosssectional area (BCSA) were detected on three limbs of uniform size on each tree, according to Westwood (1995). Fruit set, yield efficiency and crop density were determined at commercial harvest. Alternate bearing index (ABI) was calculated by the formula of Hoblyn et al. (1936) based on fluctuations of yield in successive years. We also assessed the modified alternate bearing index (MABI), developed by Racskó (2008), with flowering values instead of yield.

Average fruit weight, fruit diameter and length/diameter (L/D) were determined at 15 fruits for each tree at the harvest time. Fruit firmness (a hand-held penetrometer with $11.1 \mathrm{~mm}$ tip) and soluble solids concentration (SSC) (digital refractometer, HANNA, HI 96801) were also measured. After firmness measurements, seed numbers for each fruit were recorded.

When the F-test were statistically significant in ANOVA, means were separated using Fisher protected Least Significant Difference (LSD) with SAS- 
JMP software version 7.0 (http://www.jmp.com/software/). Piecewise linear regressions for shoot and fruit development were performed using SegReg (http://www.waterlog.info/pdf/regtxt.pdf) software.

\section{RESULTS}

The effects of Pro-Ca on mean shoot length were statistically significant throughout the threeyear period $(\mathrm{P}=0.0001)$. Pro-Ca highly reduced the shoot growth compared with the control (Table 1). Mean shoot length in Pro-Ca was $22.8 \mathrm{~cm}, 32.5 \mathrm{~cm}$, and $24.7 \mathrm{~cm}$ for 2010, 2011, and 2012, respectively, whereas in control, it was recorded as $38.2 \mathrm{~cm}$, $54.0 \mathrm{~cm}$, and $43.1 \mathrm{~cm}$, respectively. Pro-Ca application significantly reduced the internodes length compared with the control $(\mathrm{P}=0.0169)$ (Table 1). Internodes length was found as $30.1 \mathrm{~mm}$ in control and $21.0 \mathrm{~mm}$ in Pro-Ca applied shoots, whereas node numbers were similar. Shoot development of Pro-Ca applied trees and regression equations are given in Figure 1. The shoot length of control increased linearly from full bloom to 45 days after full bloom (DAFB), after that the growth decreased, and a limited growth continued until the end of growing season (Fig. 1A). The treatments of Pro-Ca significantly inhibited the shoot growth almost 30 DAFB when shoot length was $15.6 \mathrm{~cm}$ in Pro-Ca and $25 \mathrm{~cm}$ in control (Fig. 1B). The growth of Pro-Ca applied shoots increased a little again after 60 DAFB. There was no increase in control shoots at that time. The lengths of control and Pro$\mathrm{Ca}$ applied shoots were $37.2 \mathrm{~cm}$ and $18.5 \mathrm{~cm}$ respectively, in that period.

The Pro-Ca treatment did not have a significant effect on fruit development in the present study. A similar growth curve was exhibited by both control and Pro-Ca applied apples, as shown in Figure $2 \mathrm{~A}, \mathrm{~B}$. As usual, it demonstrated a linear increase in fruit diameter in the beginning of fruit growth, followed by a slow curvilinear enlargement when maturity approached.

Table 1. Effects of Pro-Ca on mean shoot length, internode length and node number of 'Golden Delicious' apple trees

\begin{tabular}{|c|c|c|c|c|c|}
\hline \multirow{2}{*}{ Treatment } & \multicolumn{3}{|c|}{ Shoot length (cm) } & \multirow{2}{*}{$\begin{array}{l}\text { Internode length } \\
(\mathrm{mm})(2012)\end{array}$} & \multirow{2}{*}{$\begin{array}{c}\text { Node number } \\
\text { (2012) }\end{array}$} \\
\hline & 2010 & 2011 & 2012 & & \\
\hline Control & $38.4 \pm 6.71 \mathrm{a}$ & $54.3 \pm 8.16 \mathrm{a}$ & $43.3 \pm 5.84 \mathrm{a}$ & $30.1 \pm 10.5 \mathrm{a}$ & $16.6 \pm 3.2 \mathrm{a}$ \\
\hline Pro-Ca & $22.8 \pm 6.72 b$ & $32.5 \pm 5.13 \mathrm{~b}$ & $24.7 \pm 4.53 \mathrm{~b}$ & $21.0 \pm 4.7 \mathrm{~b}$ & $15.4 \pm 3.2 \mathrm{a}$ \\
\hline P-value & 0.0001 & 0.0001 & 0.0001 & 0.0169 & 0.4602 \\
\hline
\end{tabular}

Within each column, different letters indicate significant differences according to LSD tests at $p=0.05$. The values are means \pm SD.

P-value - probability of F statistic
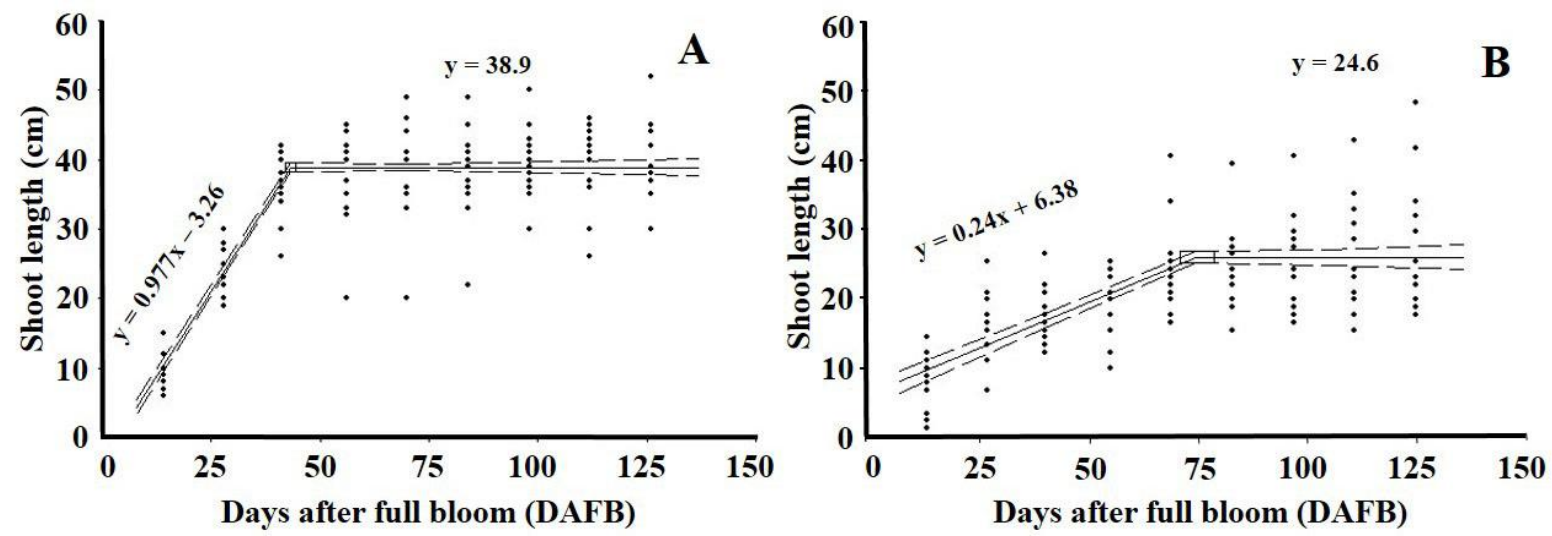

Fig. 1. Effect of Pro-Ca on shoot development in 'Golden Delicious' apple trees in 2010. A) Control, (B) Pro-Ca. Solid lines represent piecewise linear regressions, and dotted lines are the confidence bands 

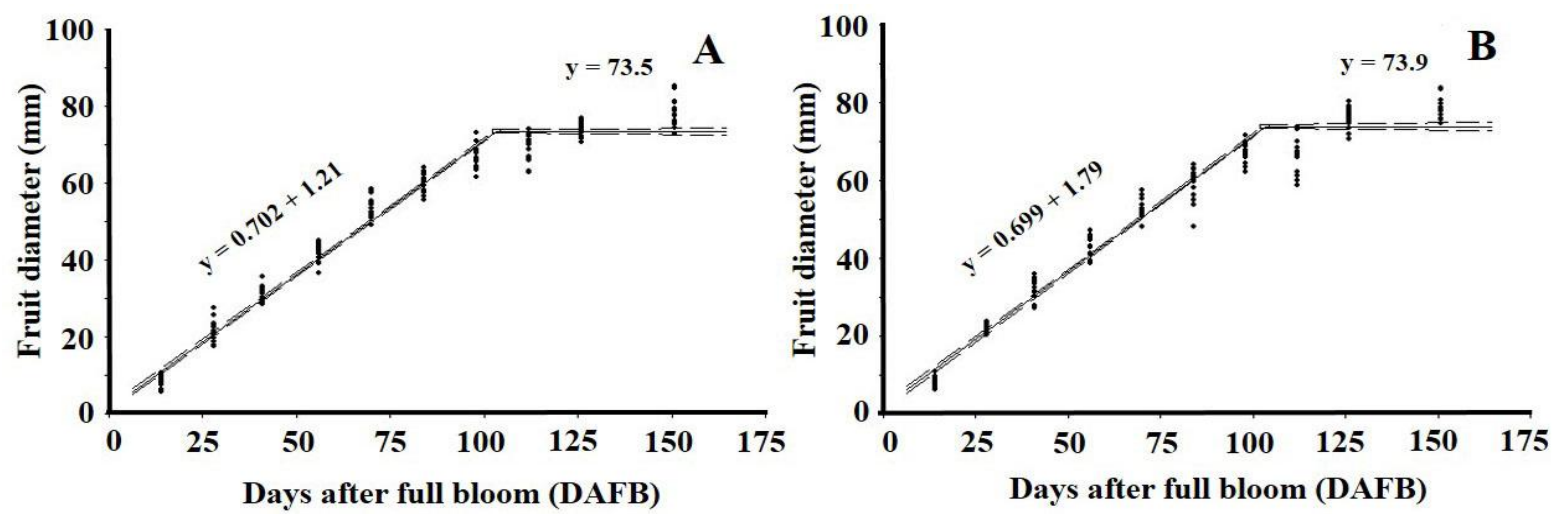

Fig. 2. Effect of Pro-Ca on fruit development in 'Golden Delicious' apple in 2010. A) Control, (B) Pro-Ca. Solid lines represent piecewise linear regressions, and dotted lines are the confidence bands

Table 2. Effects of Pro-Ca on trunk cross sectional area in 'Golden Delicious' apple trees

\begin{tabular}{lccccccc}
\hline \multirow{2}{*}{ Treatment } & \multicolumn{7}{c}{ TCSA $\left(\mathrm{cm}^{2}\right)$} \\
\cline { 2 - 7 } & Spring & Fall & Increase & Fall & Increase & Fall & Increase \\
\cline { 2 - 7 } & $13.3 \pm 3.3 \mathrm{a}$ & $16.7 \pm 3.2 \mathrm{a}$ & $3.4 \pm 1.5 \mathrm{a}$ & $24.9 \pm 5.6 \mathrm{a}$ & $8.2 \pm 3.2 \mathrm{a}$ & $27.0 \pm 6.1 \mathrm{a}$ & $2.7 \pm 2.5 \mathrm{a}$ \\
Control & $13.9 \pm 1.5 \mathrm{a}$ & $18.0 \pm 2.3 \mathrm{a}$ & $4.0 \pm 1.8 \mathrm{a}$ & $24.7 \pm 1.8 \mathrm{a}$ & $6.7 \pm 0.9 \mathrm{a}$ & $27.6 \pm 0.6 \mathrm{a}$ & $2.9 \pm 1.3 \mathrm{a}$ \\
Pro-Ca & 0.6517 & 0.4775 & 0.4830 & 0.9261 & 0.4190 & 0.8233 & 0.8459 \\
P-value & &
\end{tabular}

Within each column the same letters indicate lack of significant differences according to LSD tests at $\mathrm{p}=0.05$. TCSA: trunk cross sectional area. The measurements were performed early spring in 2010 and end of the growing season in 2010, 2011 , and 2012. The values are means \pm SD.

P-value - probability of F statistic

Table 3. Effects of Pro-Ca on flowering parameters in 'Golden Delicious' apple trees

\begin{tabular}{|c|c|c|c|}
\hline \multirow[b]{2}{*}{ Treatment } & \multicolumn{2}{|c|}{ Flower density } & \multirow[b]{2}{*}{$\begin{array}{l}\text { Flowering } \\
\text { index }\end{array}$} \\
\hline & $\begin{array}{l}\text { cluster } \\
\text { no/cm } \\
(\mathrm{TCSA}) \\
\end{array}$ & $\begin{array}{c}\text { cluster } \\
\mathrm{no} / \mathrm{cm}^{2} \\
(\mathrm{BCSA})\end{array}$ & \\
\hline \multicolumn{4}{|c|}{2010} \\
\hline Control & $5.91 \pm 1.36 \mathrm{a}$ & $3.59 \pm 1.91 \mathrm{a}$ & $0.72 \pm 0.24 \mathrm{a}$ \\
\hline Pro-Ca & $6.10 \pm 1.60 \mathrm{a}$ & $3.18 \pm 0.93 \mathrm{a}$ & $0.71 \pm 0.18 \mathrm{a}$ \\
\hline $\mathrm{P}$-value & 0.5729 & 0.4506 & 0.8187 \\
\hline \multicolumn{4}{|c|}{2011} \\
\hline Control & $0.21 \pm 0.18 \mathrm{a}$ & $0.46 \pm 0.89 \mathrm{a}$ & $0.04 \pm 0.08 \mathrm{a}$ \\
\hline Pro-Ca & $0.22 \pm 0.25 \mathrm{a}$ & $0.16 \pm 0.49 \mathrm{a}$ & $0.02 \pm 0.05 \mathrm{a}$ \\
\hline $\mathrm{P}$-value & 0.9714 & 0.2175 & 0.2134 \\
\hline \multicolumn{4}{|c|}{2012} \\
\hline Control & $9.39 \pm 1.40 \mathrm{a}$ & $5.39 \pm 3.68 \mathrm{a}$ & $0.95 \pm 0.07 \mathrm{a}$ \\
\hline Pro-Ca & $8.96 \pm 1.39 \mathrm{a}$ & $4.73 \pm 2.91 \mathrm{a}$ & $0.96 \pm 0.06 \mathrm{a}$ \\
\hline P-value & 0.6928 & 0.5723 & 0.5985 \\
\hline \multicolumn{4}{|c|}{2013} \\
\hline Control & $0.71 \pm 0.22 \mathrm{a}$ & $0.31 \pm 0.64 \mathrm{a}$ & $0.07 \pm 0.11 \mathrm{a}$ \\
\hline Pro-Ca & $0.67 \pm 0.82 \mathrm{a}$ & $0.20 \pm 0.28 \mathrm{a}$ & $0.05 \pm 0.08 \mathrm{a}$ \\
\hline P-value & 0.8994 & 0.5285 & 0.5032 \\
\hline
\end{tabular}

Table 4. Effects of Pro-Ca on yield parameters in 'Golden Delicious' apple trees

\begin{tabular}{lccc}
\hline Treatment & $\begin{array}{c}\text { Yield effi- } \\
\text { ciency } \\
\left(\mathrm{kg} / \mathrm{cm}^{2}\right)\end{array}$ & $\begin{array}{c}\text { Crop density } \\
(\text { fruit } \\
\text { no/cm }\end{array}$ & $\begin{array}{c}\text { Fruit set } \\
(\%)\end{array}$ \\
\hline Control & $1.79 \pm 0.11 \mathrm{a}$ & $9.90 \pm 0.86 \mathrm{a}$ & $36.4 \pm 6.8 \mathrm{a}$ \\
Pro-Ca & $1.67 \pm 0.06 \mathrm{a}$ & $9.36 \pm 0.48 \mathrm{a}$ & $32.8 \pm 6.4 \mathrm{a}$ \\
P-value & 0.1578 & 0.2090 & 0.2530 \\
\hline \multicolumn{4}{c}{2011} \\
\hline Control & $0.07 \pm 0.05 \mathrm{a}$ & $0.34 \pm 0.30 \mathrm{a}$ & $39.1 \pm 31.1 \mathrm{a}$ \\
Pro-Ca & $0.04 \pm 0.01 \mathrm{a}$ & $0.20 \pm 0.06 \mathrm{a}$ & $31.7 \pm 13.9 \mathrm{a}$ \\
P-value & 0.2255 & 0.2193 & 0.4634 \\
\hline \multicolumn{4}{c}{2012} \\
\hline Control & $1.39 \pm 0.15 \mathrm{a}$ & $11.45 \pm 1.57 \mathrm{a}$ & $22.3 \pm 4.4 \mathrm{a}$ \\
Pro-Ca & $1.21 \pm 0.42 \mathrm{a}$ & $9.20 \pm 3.24 \mathrm{a}$ & $18.6 \pm 3.6 \mathrm{a}$ \\
P-value & 0.2273 & 0.0711 & 0.0616 \\
\hline
\end{tabular}

Note: see Table 3 
There was no significant influence of Pro-Ca application on tree trunk growth over the 3-trail years although TCSA relatively increased year to year (Table 2). However, the flowering and yield parameters of Pro-Ca treated trees were not different than the control (Table 3, 4). Besides, high alternate bearing intensities were detected both in control (0.92) and Pro-Ca (0.97) trees (Table 5).

Pro-Ca treatments did not cause any significant differences on fruit weight and diameter in 2010 and 2011 (Table 6). However, fruit diameter of Pro-Ca was greater than control in 2012 $(\mathrm{P}=0.0241)$. No differences in $\mathrm{L} / \mathrm{D}$ or SSC were noted for three years. Pro-Ca relatively affected fruit firmness in the first 2 years, but not in the last year, however firmness values ranged between 6.4 and
$7.4 \mathrm{~kg}$ in the three-year period. Seed numbers did not show differences between the control and the Pro-Ca treated trees (Table 6).

Table 5. Effects of Pro-Ca on ABI (2010-2012) and MABI (2010-2013) in 'Golden Delicious' apple trees

\begin{tabular}{lcccc}
\hline Treatment & \multicolumn{2}{c}{ ABI } & \multicolumn{2}{c}{ MABI } \\
\hline Control & $0.93 \pm 0.07$ a & high* & $0.91 \pm 0.05$ a & high \\
Pro-Ca & $0.97 \pm 0.02$ a & high & $0.93 \pm 0.03$ a & high \\
P-value & 0.3218 & 0.6595 & \\
\hline
\end{tabular}

Within each column, different letters indicate significant differences according to LSD tests at $\mathrm{p}=0.05$. ABI: alternate bearing index. MABI: modified alternate bearing index. The values are means $\pm \mathrm{SD}$. "Index values were grouped according to Racskó (2008)

P-value - probability of F statistic

Table 6. The effects of Pro-Ca on some features of fruit quality in 'Golden Delicious' apple

\begin{tabular}{lcccccc}
\hline Treatment & $\begin{array}{c}\text { Fruit weight } \\
(\mathrm{g})\end{array}$ & $\begin{array}{c}\text { Fruit diameter } \\
(\mathrm{mm})\end{array}$ & $\mathrm{L} / \mathrm{D}$ & $\begin{array}{c}\text { Firmness } \\
(\mathrm{kg})\end{array}$ & $\begin{array}{c}\text { SSC } \\
(\%)\end{array}$ & Seed number \\
\hline Control & $208.8 \pm 28.5 \mathrm{a}$ & $78.8 \pm 3.9 \mathrm{a}$ & $0.92 \pm 0.04 \mathrm{a}$ & $6.9 \pm 0.6 \mathrm{a}$ & $12.6 \pm 0.8 \mathrm{a}$ & $7.1 \pm 2.4 \mathrm{a}$ \\
Pro-Ca & $212.4 \pm 33.7 \mathrm{a}$ & $78.9 \pm 4.2 \mathrm{a}$ & $0.92 \pm 0.04 \mathrm{a}$ & $6.4 \pm 0.4 \mathrm{~b}$ & $12.3 \pm 0.6 \mathrm{a}$ & $6.9 \pm 1.5 \mathrm{a}$ \\
$\mathrm{P}$-value & 0.5292 & 0.7982 & 0.7927 & 0.0001 & 0.1495 & 0.8082 \\
\hline \multicolumn{7}{c}{2011} \\
\hline Control & $203.0 \pm 27.6 \mathrm{a}$ & $76.9 \pm 3.6 \mathrm{a}$ & $0.94 \pm 0.04 \mathrm{a}$ & $7.4 \pm 0.4 \mathrm{a}$ & $14.8 \pm 1.1 \mathrm{a}$ & $5.2 \pm 2.2 \mathrm{a}$ \\
Pro-Ca & $193.8 \pm 60.6 \mathrm{a}$ & $76.0 \pm 7.2 \mathrm{a}$ & $0.96 \pm 0.10 \mathrm{a}$ & $6.9 \pm 1.0 \mathrm{~b}$ & $15.0 \pm 0.1 \mathrm{a}$ & $5.6 \pm 2.2 \mathrm{a}$ \\
P-value & 0.3001 & 0.4871 & 0.1656 & 0.0412 & 0.3142 & 0.4280 \\
\hline \multicolumn{7}{c}{2012} \\
\hline Control & $141.3 \pm 22.6 \mathrm{~b} *$ & $68.3 \pm 3.9 \mathrm{~b}$ & $0.94 \pm 0.03 \mathrm{a}$ & $6.9 \pm 1.0 \mathrm{a}$ & $13.5 \pm 1.0 \mathrm{a}$ & $6.3 \pm 2.0 \mathrm{a}$ \\
Pro-Ca & $155.9 \pm 23.1 \mathrm{a}$ & $70.3 \pm 3.8 \mathrm{a}$ & $0.94 \pm 0.04 \mathrm{a}$ & $7.0 \pm 0.5 \mathrm{a}$ & $13.8 \pm 0.5 \mathrm{a}$ & $6.0 \pm 2.3 \mathrm{a}$ \\
P-value & 0.0034 & 0.0241 & 0.3348 & 0.4262 & 0.1341 & 0.6122 \\
\hline
\end{tabular}

*Within each column, different letters within year indicate significant differences according to LSD tests at $\mathrm{p}=0.05$. $\mathrm{L} / \mathrm{D}$ : length/diameter ratio. SSC: soluble solids concentration. The values are means $\pm \mathrm{SD}$.

P-value - probability of F statistic

\section{DISCUSSION}

There have been numerous experiments about the control of vegetative and reproductive growth of fruit trees with retardants, but apparently almost all of them lasted only one year. This study was initiated to document the long-term effects of continual Pro-Ca application on the same trees. Greene (2008) also reported results of multiple-year applications of Pro-Ca. However, that study was conducted on semi-intensive orchard and carried out on 'Mutsu' and 'McIntosh' apple cvs grafted on M.7. We investigated response of intensive apple orchards grafted on dwarf rootstock M.9. Because intensive orchards are crucial for modern fruit production (Robinson 2003), the control of vegetative growth is a fundamental principle in intensive orchards.

The most evident effect of Pro-Ca in the current study was the decrease of shoot length. Compared to control, Pro-Ca reduced the shoot length by $40 \%$ in 2010 and 2011 and by $43 \%$ in 2012. Pro-Ca helps to reduce the growth due to inhibition of $\mathrm{GA}_{1}$ 
prolong shoots by stimulating cell growth and division (Wertheim \& Webster 2005). Treatment with Pro-Ca reduced shoot length by $21-71 \%$ in apples depending on the dose, timing of treatment and cultivar (Miller 2002). Similar effects were observed in 'Smoothee Golden Delicious' (Medjdoub et al. 2004), 'Empire' (Cline et al. 2008), and 'Royal Gala' and 'Fuji' (Mata et al. 2006) apple trees. These reports accord with our findings showing that Pro-Ca inhibits the lengthening of apple shoots. The shoots of both control and Pro-Ca treated trees were longer in the 2011 than in 2010 and 2012 due to the deterioration of vegetative and generative balance. Indeed, the 'Golden Delicious' has a strong tendency to alternate bearing in Isparta/Turkey (Atay et al. 2013). Medjdoub et al. (2004) and Mata et al. (2006) reported that reduction in shoot growth is mainly the result of shortening of internodes. In our experiment, Pro-Ca reduced the length of the internodes by about $30 \%$, while total node number in shoot was unaffected.

Apple shoots grow most rapidly after bloom and follow a sigmoid growth curve (Greene \& Autio 1994). However, in our trial, a regrowth occurred at 60 DAFB in Pro-Ca applied shoots. The limited half-life of Pro-Ca indicates its short-lived effects (Wertheim \& Webster 2005). In fact, the second Pro-Ca application of this experiment was performed at 30-40 DAFB. It is evident that repeated sprays of Pro-Ca have been a limiting factor in the efficiency of treatments as well as the time of application (Miller 2002; Cline 2006). In this trial, the shoot growth of 'Golden Delicious' apple trees continued until 70 DAFB in control, but more than $80 \%$ of the total shoot growth was completed in 45 DAFB. The second spray must be applied before 45 DAFB for effectively controlling the regrowth of shoots.

Fruit diameters were regularly measured to reveal the physical fruit growth dynamics in the Pro$\mathrm{Ca}$ application from petal fall to harvest time. Conversely to shoot elongation, Pro-Ca treated apples had a similar growth curve to the control. The effects of Pro-Ca on fruit development were similar to control. It is evident that Pro-Ca had a direct effect on shoot growing, but it had no effect on fruit development in apple.
Agents blocking GA biosynthesis and activity have been generally observed to promote flower bud formation (Faust 1989). However, Pro-Ca, a GA inhibitor, had no evident effect on flowering, yield and alternate bearing in our study. Similar observations were also found by Cline et al. (2008) and Duyvelshoff and Cline (2013). Byers et al. (2004) reported that the effect of Pro-Ca on flowering is neutral.

There are contrary findings revealing the relationship between Pro-Ca and fruit set. While Medjdoub et al. (2005) and Greene (2008) have reported that Pro-Ca increases fruit set, other researchers explained it as ineffective (Costa et al. 2000; Miller 2002). In the present study, Pro-Ca has no significant influence on fruit set compared to control. As a matter of fact, like many PGRs, the effects of Pro-Ca could vary according to cultivar. In the study of Medjdoub et al. (2005), Pro-Ca was effective in 'Gala' but not in 'Fuji' to increase the fruit set. In addition, fruit set increased especially above $125 \mathrm{mg} \mathrm{dm}^{-3}$ of Pro-Ca (Byers et al. 2004). Therefore, possible side effects were minimal in low-dose Pro-Ca (Greene 2008).

Although there has been no reported disadvantage of Pro-Ca treatment related to fruit quality, long-term monitoring of the Pro-Ca effects on the same trees has been suggested (Wertheim \& Webster 2005). In our research, Pro-Ca had no bad influence on fruit quality compared to control throughout the three consecutive years. Additionally, Pro-Ca resulted in higher fruit weight and diameter values compared to control in the last trial year. It could be the effect of the reduction of competition between growing shoot tips and developing fruitlets for assimilates, nutrients and hormones because the growing shoot tips are characterized with much stronger sink for metabolites than fruitlets (Treharne et al. 1985). There was high correlation between seed number and fruit quality parameters in apple (Buccheri \& Di Vaio 2004; Blažek \& Hlušičková 2006). In our experiment, Pro-Ca treatment had no effect on seed number for three years like fruit set.

\section{CONCLUSIONS}

Pro-Ca is a good agent for vigor control in intensive apple orchard. After a full canopy has been 
achieved, the annual shoot growth can be suppressed in the range of 20 to $30 \mathrm{~cm}$ with $125 \mathrm{mg} \mathrm{dm}^{-3}$ ProCa treatment in 'Golden Delicious' apple trees without having any negative effects on fruit quality and yield parameters.

\section{Acknowledgements}

We thank Süleyman Demirel University (SDU), Scientific Research Projects Unit for financially supporting the study. We also thank Dr. Ozgur Koskan (SDU, Turkey) for helpful discussions on piecewise linear regression.

\section{REFERENCES}

Asín L., Alegre S., Montserrat R. 2007. Effects of paclobutrazol, prohexadione-Ca, deficit irrigation, summer pruning and root pruning on shoot growth, yield, and return bloom, in a 'Blanquilla' pear orchard. Scientia Horticulturae 113: 142-148. DOI: 10.1016/j.scienta.2007.02.008.

Atay A.N., Koyuncu F., Atay E. 2013. Relative susceptibility of selected apple cultivars to alternate bearing. Journal of Biological and Environmental Sciences 7: 81-86.

Blažek J., Hlušičková I. 2006. Seed count, fruit quality and storage properties in four apple cultivars. Journal of Fruit and Ornamental Plant Research 14, Supplement 2: 151-160.

Buccheri M., Di Vaio C. 2004. Relationship among seed number, quality, and calcium content in apple fruits. Journal of Plant Nutrition 27: 1735-1746. DOI: $10.1081 /$ lpla-200026409.

Byers R.E., Carbaugh D.H., Combs L.D. 2004. The influence of prohexadione-calcium sprays on apple tree growth, chemical fruit thinning and return bloom. Journal of the American Pomological Society 58: 111-117.

Cline J.A. 2006. Apogee ${ }^{\circledR}$ - a new plant bioregulator for apples. Factsheet, 06-045, Queen's Printer for Ontario, Toronto.

Cline J.A., Embree C.G., Hebb J., Nichols D.S. 2008. Performance of prohexadione-calcium on shoot growth and fruit quality of apple - effect of spray surfactants. Canadian Journal of Plant Science 88: 165-174. DOI: $10.4141 /$ cjps07087.

Costa G., Bregoli A.M., Sabatini E., Cristina B., Giannina V. 2000. Apogee ${ }^{\mathrm{TM}}$ controls shoot growth and fruit parameters. HortScience 35: 421.

Costa G., Andreotti C., Sabatini E., Bregoli A.M., Bucchi F., Spada G., Mazzini F. 2002. The effect of
prohexadione-Ca on vegetative and cropping performance and fire blight control of pear trees. Acta Horticulturae 596: 531-534. DOI: 10.17660/actahortic.2002.596.89.

Duyvelshoff C., Cline J.A. 2013. Ethephon and prohexadione-calcium influence the flowering, early yield, and vegetative growth of young 'Northern Spy' apple trees. Scientia Horticulturae 151: 128-134. DOI: 10.1016/j.scienta.2012.12.002.

Elfving D.C., Lombardini L., Mcferson J.R., Drake S.R., Faubion D.F., Auvil T.D. et al. 2003. Effects of directed applications of prohexadione-calcium to tops of mature pear trees on shoot growth, light penetration, pruning and fruit quality. Journal of American Pomological Society 57: 45-57.

Elfving D.C., Lang G.A., Visser D.B. 2005. Effects of prohexadione-calcium and ethephon on growth and flowering of 'Bing' sweet cherry. Acta Horticulturae 667: 439-446. DOI: 10.17660/actahortic.2005.667.63.

Evans J.R., Evans R.R., Regusci C.L., Rademacher W. 1999. Mode of action, metabolism, and uptake of BAS $125 \mathrm{~W}$, prohexadione-calcium. HortScience 34: 1200-1201.

Faust M. 1989. Physiology of Temperate Zone Fruit Trees. John Wiley and Sons, New York, USA, 338 p.

Forshey C.G., Elfving D.C. 1989. The relationship between vegetative growth and fruiting in apple trees. Horticultural Reviews 11: 229-287. DOI: 10.1002/9781118060841.ch7.

Forshey C.G., Elfving D.C., Stebbins R.L. 1992. Training and pruning of apple and pear trees. American Society for Horticultural Science, USA, $166 \mathrm{p}$.

Garner L.C., Zheng Y., Khuong T., Lovatt C.J. 2010. Prohexadione-calcium affects shoot growth of evergreen subtropical woody perennials differently than deciduous temperate zone woody perennials is it a case of apples and oranges? Acta Horticulturae 884: 249-256. DOI: 10.17660/actahortic.2010.884.29.

Greene D.W. 1999. Tree growth management and fruit quality of apple trees treated with prohexadionecalcium (Bas 125). HortScience 34: 1209-1212.

Greene D.W. 2008. The effect of repeat annual applications of prohexadione-calcium of fruit set, return bloom, and fruit size of apples. HortScience 43: 376-379.

Greene D.W., Autio W.R. 1994. Notching techniques increase branching of young apple trees. Journal of the American Society for Horticultural Science 119: 678-682. 
Greene D.W., Autio W.R. 2002. Apogee ${ }^{\circledR}-$ a new growth retardant for apples. Fruit Program, University of Massachusetts Extension Factsheet F-127R.

Hoblyn T.N., Grubb N.H., Painter A.C., Wates B.L. 1936. Studies on biennial bearing - I. Journal of Pomology and Horticultural Science 14: 39-76. DOI: 10.1080/03683621.1937.11513464.

Jacyna T., Barnard J., Wielgus M. 2012. Immediate and residual effects of prohexadione-calcium, with or without ethephon, applied in a low-pH solution on vegetative and reproductive growth in sweet cherry trees (Prunus avium L.). Journal of Horticultural Science and Biotechnology 87: 577-582. DOI: 10.1080/14620316.2012.11512914.

Mata A.P., Val J., Blanco A. 2006. Differential effects of prohexadione-calcium on red colour development in 'Royal Gala' and 'Fuji' apples. Journal of Horticultural Science and Biotechnology 81: 84-88. DOI: 10.1080/14620316.2006.11512033.

Medjdoub R., Val J., Blanco A. 2004. Prohexadione-Ca inhibits vegetative growth of 'Smoothee Golden Delicious' apple trees. Scientia Horticulturae 101: 243-253. DOI: 10.1016/j.scienta.2003.11.005.

Medjdoub R., Val J., Blanko A. 2005. Inhibition of vegetative growth in red apple cultivars using prohexadione-calcium. Journal of Horticultural Science and Biotechnology 80: 263-271. DOI: 10.1080/14620316.2005.11511927.

Miller S.S. 2002. Prohexadione-calcium controls vegetative shoot growth in apple. Journal of Tree Fruit Production 3: 11-28. DOI: 10.1300/J072v03n01_02.

Racskó J. 2008. Crop autoregulation of apple on different growth inducing rootstocks. PhD Thesis, University of Debrecen, Hungary.
Rademacher W., Kober R. 2003. Efficient use of prohexadione-Ca in pome fruits. European Journal of Horticultural Science 68: 101-107.

Robinson T.L. 2003. Apple-orchard planting systems. In: Ferree D.C., Warrington I.J. (Eds.), Apples: Botany, Production and Uses. CABI Publishing, Cambridge, pp. 345-407. DOI: 10.1079/9780851995922.0345.

Solar A., Jakopič J., Veberič R., Štampar F. 2008. Prohexadione-Ca affects vegetative growth of the rejuvenated shoots in walnut trees. HortScience 43: $558-561$.

Treharne K.J., Quinlan J.D., Knight J.N., Ward D.A. 1985. Hormonal regulation of fruit development in apple: 'A mini-review'. Plant Growth Regulation 3: 125-132. DOI: 10.1007/BF01806052.

Tromp J. 2005. Flower-bud formation. In: Tromp J., Webster A.D., Wertheim S.J. (Eds.), Fundamentals of Temperate Zone Tree Fruit Production. Backhuys Publishers BV, Leiden, The Netherlands, pp. 204-215.

TSI 2013. Turkish Statistical Institute. http://www.turkstat.gov.tr/Start.do (accessed November 10 ${ }^{\text {th }}, 2013$ )

Unrath C.R. 1999. Prohexadione-Ca: a promising chemical for controlling vegetative growth of apples. HortScience 34: 1197-1200.

Wertheim S.J., Webster A.D. 2005. Manipulation of growth and development by plant bioregulators. In: Tromp J., Webster A.D., Wertheim S.J. (Eds.), Fundamentals of Temperate Zone Tree Fruit Production. Backhuys Publishers BV, Leiden, The Netherlands, pp. 267-294.

Westwood M.N. 1995. Temperate Zone Pomology: Physiology and Culture. Timber Press, Oregon, 523 p. 